\title{
Getúlio Vargas e o Supremo Tribunal Federal: uma análise do habeas corpus de Olga Prestes
}

\author{
Getúlio Vargas and the Brazilian Supreme Court: an analysis of \\ Olga Prestes' habeas corpus
}

Felipe Cittolin Abal ${ }^{1}$

RESUMO

O presente artigo trata a respeito do julgamento pela Corte Suprema brasileira do habeas corpus impetrado em nome de Olga Benário Prestes com fins de impedir a sua expulsão do Brasil para a Alemanha nazista. O principal objetivo do estudo é identificar, através da análise da decisão do Tribunal, os fatores que levaram à negação do habeas corpus, levando-se em conta a composição da Corte, as regras existentes para o caso, as relações entre o poder executivo e o Tribunal e a relação entre o governo de Vargas e a Corte Suprema. Através do estudo deste caso específico é possível reconhecer que a Corte Suprema brasileira possuía uma forte relação com o poder executivo consubstanciado na figura de Vargas, o que levou a uma decisão alinhada com os anseios do então presidente.

Palavras chave: Expulsão. Corte Suprema. Olga Benário Prestes. Vargas.

ABSTRACT

This article deals with the judgment by the Brazilian Supreme Court of the habeas corpus filed in the name of Olga Benário Prestes in order to prevent her expulsion from Brazil to Nazi Germany. The main objective of the study is to identify, through the analysis of the Court's decision, the factors that led to the denial of the habeas corpus, taking into account the composition of the Court, the existing rules for the case, the relations between the executive and the Court and the relationship between Vargas government and the Supreme Court. Through the study of this specific case it is possible to recognize that the Brazilian Supreme Court had a strong relation with the executive power embodied in the figure of Vargas, which led to a decision aligned with the wishes of the president.

Keyword: Expulsion. Supreme Court. Olga Benário Prestes. Vargas.

${ }^{1}$ Doutor em História pela Universidade de Passo Fundo. Professor da Faculdade de Direito e do Programa de Pós-Graduação em História da Universidade de Passo Fundo. 


\section{Considerações Iniciais}

A expulsão de Olga Benário Prestes durante o governo Vargas no Brasil não se trata de uma questão nova nos estudos históricos. Diversas produções científicas tratam a respeito de seu relacionamento com Luís Carlos Prestes, sua atuação no país e sua expulsão para a Alemanha nazista (REIS, 2014; PRESTES, 2017; MORAIS, 2008). O presente artigo, porém, tem por intuito investigar uma parte de extrema importância envolvendo Olga Prestes e sua expulsão: a atuação do Supremo Tribunal Federal (denominado Corte Suprema à época) no julgamento do habeas corpus impetrado em favor de Olga diante do contexto histórico-político da época.

Assim, o foco principal do presente artigo é analisar a decisão prolatada pela Corte Suprema, negando o habeas corpus, tendo em vista a formação do Tribunal, o contexto histórico, a atuação anterior dos ministros que compunham a Corte e as regras ${ }^{1}$ que poderiam ser utilizadas ao julgar o caso.

A importância das Cortes Supremas e do Poder Judiciário para a história é reconhecida pelos historiadores, uma vez que existem diversas intersecções e momentos de influência mútua entre o direito e as instituições judiciais e a história (KOERNER, 2010). Sabendo desta importância é que pode ser vista a relevância deste artigo, no qual poderá ser vista, através da análise da decisão e do processo decisório do caso em tela, as relações existentes entre a Corte Suprema e o poder executivo.

Para que seja possível a análise da decisão da Corte Suprema será realizada, em um primeiro momento, uma exposição acerca do relacionamento entre Luis Carlos Prestes e Olga Benário Prestes e da atuação, especialmente do primeiro, na chamada "Intentona" Comunista de 1935, uma vez que este fato se tratou do estopim que levou à prisão de Prestes e Olga. Na sequência será estudada a composição da Corte Suprema brasileira (Supremo Tribunal Federal) quando do julgamento do caso, a relação entre Vargas e a Corte e as regras que deveriam ser utilizadas pelos julgadores.

Por fim, serão analisados os votos que compõem o acórdão, buscando os argumentos utilizados pelos julgadores para negar o habeas corpus em nome de Olga Prestes. Através deste estudo será possível identificar os motivos que levaram à decisão, desde os relacionados a fatores pessoais dos julgadores (atuação prévia e ligação com o poder executivo), as regras que poderiam ser utilizadas para fundamentar as decisões, a relação entre a Corte e o poder executivo até o contexto histórico em que a decisão foi prolatada.

Quanto às fontes utilizadas para o artigo, destaca-se que todas as citações de excertos do habeas corpus foram retirados da peça elaborada pelo advogado de Olga Prestes e aquelas referentes aos votos foram obtidas no acórdão disponibilizado pelo Supremo Tribunal Federal.

${ }^{1}$ Para fins deste artigo é utilizado o termo regras em sentido lato, ou seja, abrangendo leis, decretos e dispositivos constitucionais. 
Em relação à metodologia, será seguida a análise de fatores que podem ter impacto no processo decisório dos julgadores conforme exposto por Abal (2016) na denominada técnica históricojurídica de análise das decisões judiciais.

Através desta técnica têm-se como necessário para a compreensão do resultado de um processo judicial (decisão) a análise de determinados fatores que podem ter impacto no processo decisório dos julgadores, especialmente, para o caso em tela, os antecedentes dos julgadores, as normas legais utilizadas, as partes (Olga e poder executivo) e o contexto histórico/político da época em que a decisão foi tomada (ABAL, 2016, p. 184-198). Partindo destes pressupostos é possível iniciar o presente artigo a partir de uma breve exposição a respeito de Olga Prestes e sua atuação no Brasil.

\section{Olga e Prestes: retorno do exílio e prisão}

Em fins de 1934 Luís Carlos Prestes, ex-líder da Coluna que atravessou o Brasil entre 1925 e 1927, preparava seu retorno ao país depois de três anos de exílio na União Soviética. Para acompanha-lo a Internacional Comunista destacou diversos profissionais, desde assessores de direção política, um especialista em comunicações, um perito em explosivos, um encarregado para as finanças, até uma encarregada da segurança de Prestes: Olga Benário, alemã que adotara na União Soviética o nome Olga Sinek (REIS, 2014, p. 168-169).

Olga, apesar de dez anos mais jovem do que Prestes, era uma militante experimentada. Com apenas 15 anos havia ingressado nas fileiras da organização juvenil do Partido Comunista Alemão e participou de diversos conflitos contra movimentos de direita em Berlim. Presa com seu namorado, Otto Braun, liderou, após sua libertação, a fuga de Otto. Agora sua missão era, durante seis meses, prover a segurança de Prestes para que ele pudesse iniciar um trabalho revolucionário no Brasil (REIS, 2014, p. 170-171).

Olga e Prestes partiram de Moscou simulando serem um casal em 29 de dezembro de 1934 e só chegaram ao Rio de Janeiro quatro meses depois, após realizarem diversas escalas para assegurar a segurança da missão. O país em que chegavam agora havia sofrido diversas vicissitudes desde o exílio de Prestes. Quando da sua chegada ao Rio de Janeiro em abril de 1935 uma figura política de destaque na história brasileira detinha o poder: Getúlio Vargas.

Getúlio já havia passado por diversas provações desde sua chegada à presidência em 1930. Três anos antes da chegada de Prestes e Olga, em 1932, sufocou a Revolução Constitucionalista paulista, com o auxílio das forças federais comandadas pelo general Góes Monteiro e pelas forças militares estaduais de Minas Gerais e do Rio Grande do Sul. As eleições para a Assembleia Constituinte em maio de 1933 haviam sido favoráveis para Vargas e o resultado de sua atuação, a Constituição de 1934, foi um documento jurídico notável (SKIDMORE, 2007, p. 38-40). Eram garantidas as eleições livres, a imparcialidade do judiciário e, pela primeira vez na história brasileira, os direitos sociais eram alçados ao âmbito constitucional. 
A mesma Assembleia, transformada em Congresso Nacional, elegeu Getúlio para o cargo de presidente em 1934 até que eleições diretas fossem realizadas em janeiro de 1938. Até que esta data chegasse, porém, muitos fatos ainda estavam por ocorrer. Os grupos políticos afeitos a Vargas, ligados ao constitucionalismo liberal e ao reformismo socioeconômico estavam sendo superados por um novo tipo de política mais radical. De um lado, os integralistas, liderados por Plínio Salgado e inspirados no fascismo europeu, e de outro a Aliança Nacional Libertadora (ANL), ligada ao Partido Comunista, cujo quadro de militantes crescia exponencialmente e contava com um líder aclamado: Luís Carlos Prestes (SKIDMORE, 2007, p. 41).

Pouco após a chegada de Prestes ao país, em 05 de julho de 1935, no aniversário da revolta tenentista no Forte de Copacabana, o líder da ANL já expunha seus pensamentos contrários a Getúlio em um manifesto lido em comício:

Os trabalhadores de todo o Brasil demonstram, através de lutas sucessivas, que já não podem mais suportar e nem querem mais se submeter ao governo em decomposição de Vargas e seus asseclas nos Estados. Além disso, os cinco últimos anos deram uma grande experiência a todos em que no Brasil tiveram de suportar e sofrer a malabarista e nojenta dominação getuliana. E esses cinco anos de manobras e traições, de contradanças de homens do poder, de situacionistas que passam a oposicionistas e vice-versa, de inimigos "irreconciliáveis" que se abraçam, cinicamente, sobre os cadáveres ainda quentes dos lutadores de 1922, abriram os olhos de muita gente. Onde estão as promessas de 1930? Que diferença entre o que se dizia e se prometia em 1930 e a tremenda realidade já vivida nestes cinco anos getulianos! (PRESTES, 1935)

Este manifesto foi utilizado pelo governo como pretexto para jogar a ANL na ilegalidade, enquanto alguns líderes do movimento colocavam sobre Prestes a culpa pelo ocorrido no seu "demasiado radicalismo", outros ligados ao Partido Comunista rejeitavam a tática de frente popular, pedindo um levante armado contra Vargas. Enquanto as discussões internas seguiam, um evento interrompeu os debates. Em 23 de novembro eclodiu em Natal uma quartelada promovida por militares revolucionários, seguidos no dia seguinte pelos seus camaradas em Recife. Não podendo mais adiar a sua adesão, no dia 27 os comunistas iniciaram suas ações no Rio de Janeiro.

A insurreição se daria de forma simultânea no $3^{\circ}$ Regimento de Infantaria da Praia Vermelha, na Escola de Aviação Militar, em alguns quartéis da Vila Militar e na Marinha de Guerra. Depois disso brigadas de operários auxiliariam o levante na cidade, desconcertando as defesas do governo (REIS, 2014, p. 186). A possibilidade de vitória era grande aos olhos dos comunistas.

Às quatro horas da manhã um telefonema acordou Vargas. O general Pantaleão Pessoa informava que uma hora antes a Escola de Aviação e o $3^{\circ}$ Regimento de Infantaria haviam 
sido alvos do movimento comunista. Getúlio permaneceu ao telefone em contato com os militares até o amanhecer, quando foi confirmado que a situação estava controlada e as demais guarnições do Rio de Janeiro permaneciam leais ao governo. Nada do que ocorrera foi uma surpresa para Vargas, a rede de informações do governo já havia sido informada através de Londres a respeito de todos os planos comunistas.

A rebelião em Natal durou quatro dias, no Recife, um, e no Rio de Janeiro, algumas horas. Restava agora a Prestes e seus aliados abrigarem-se contra a ação da polícia. Quanto a Vargas, este só desejava punir os insurgentes e, para isto, até mesmo a Lei de Segurança Nacional existente à época era por demais branda. Com a opinião pública de seu lado, Vargas conseguiu aprovar em 17 de dezembro três emendas à Constituição com vistas a atacar os comunistas. A mais importante delas o autorizava a equiparar a "comoção intestina grave" ao estado de guerra, momento em que grande parte das garantias constitucionais seriam suspensas (FAUSTO, 1995, p. 361).

Agora, mais do que nunca, Getúlio possuía a lei ao seu lado para esmagar seus opositores. Como destaca José Murilo de Carvalho, o governo fez bom uso da revolta, utilizando-a para "expulsar do Exercito os elementos mais radicais e para exagerar o perigo de uma revolta comunista no país. Criou, com o apoio do Congresso, um Tribunal de Segurança Nacional para julgar crimes políticos" (CARVALHO, 2002, p. 104). De um lado, Vargas acenava ao povo com direitos sociais, de outro, retirava direitos políticos e reprimia aqueles contrários ao seu regime (CARVALHO, 2017, p. 130).

Segundo Vianna o governo brasileiro pediu ajuda ao Intelligence Service inglês e à Gestapo nazista para identificar quem eram os revolucionários estrangeiros, enquanto Filinto Müller iniciava a repressão contra todos os opositores do governo, desde os comunistas e aliancistas até os demais democratas (VIANNA, 2007, p. 97).

Pouco a pouco o aparelho policial capturou os envolvidos na denominada "Intentona" Comunista. Em dezembro foi preso José Francisco de Campos, logo depois Orlando Leite Ribeiro e no final do mês Arthur Ewert e sua esposa. As detenções continuaram até o dia 05 de março de 1936, quando foram presos Prestes e Olga. O período em que fugiram da captura também havia sido o em que seu relacionamento amoroso havia aflorado com maior intensidade e durante o qual Olga engravidou. Depois de sua prisão Olga e Prestes foram separados no hall da Polícia Central. Eles nunca mais se encontrariam (REIS, 2014, p. 19-198). Três meses depois o destino de Olga seria decidido pela Corte Suprema brasileira (Supremo Tribunal Federal).

\section{Getúlio Vargas e o Supremo Tribunal Federal}

Desde sua chegada ao poder, Vargas deixou clara a sua vontade de intervir no Supremo Tribunal Federal (STF). Já no decreto que instituía o governo provisório era prevista a criação de um Tribunal Especial para julgar crimes políticos e outros constantes em sua lei de organização. Em fevereiro de 1931 outro decreto reduziu o número de ministros do STF de 
quinze para onze. Alguns dias depois Vargas aposentou compulsoriamente seis membros do Tribunal: Antônio Joaquim Pires de Carvalho e Albuquerque, Edmundo Muniz Barreto, Pedro Afonso Mibielli, Godofredo Cunha, Geminiano da Franca e Pedro Joaquim Santos, nomeando dois ministros, Joao Martins de Carvalho Mourão e Plínio Casado (COSTA, 2006, p. 70-71).

Pode-se inferir que a intervenção de Vargas no Supremo Tribunal Federal servia para resolver duas questões: primeiramente, fazia parte de seu projeto de livrar os órgãos estatais de pessoas ligadas à elite política da República Velha, podendo-se registrar, ainda, que a aposentadoria compulsória dos ministros poderia servir como um ato de vingança por eles terem votado contra os revolucionários de 1922, 23 e 24, como expõe Emília Viotti da Costa:

Essa interpretação é difícil de ser comprovada. No entanto, analisando-se o desempenho dos ministros por meio dos julgados, observa-se que não só eles haviam negado vários habeas corpus impetrados em favor dos tenentes, como também, com exceção talvez de Mibelli, constituíram um bloco ultraconservador no Supremo Tribunal Federal (COSTA, 2006, p. 71).

Em segundo lugar, sabendo da importância do STF, mesmo diante do esvaziamento de sua competência em virtude da criação de outros tribunais, era do interesse de Vargas nomear pessoas para ocupar os postos no Tribunal, pretendendo que eles julgassem de acordo com o interesse do Executivo.

A Constituição de 1934, por sua vez, também trouxe mudanças para o Supremo Tribunal Federal. O artigo 63 alterou a denominação do Tribunal, designando-o como Corte Suprema. $\mathrm{O}$ artigo seguinte, que versava sobre as garantias dos membros do judiciário, previa a vitaliciedade dos juízes, porém estabelecia a aposentadoria compulsória aos 75 anos de idade, limitação inexistente anteriormente. A Constituição de 1937 traria outras limitações e mudanças em relação ao STF, porém, para fins deste artigo, nos limitaremos ao período do julgamento do habeas corpus de Olga Prestes.

Como foi visto, já nos primeiros instantes de seu governo, Vargas aposentou compulsoriamente seis ministros e nomeou dois. Quando do julgamento do habeas corpus de Olga Prestes, em junho de 1936, a Corte já estava quase completamente reformulada. Contando com o falecimento e a aposentadoria de grande parte dos ministros empossados antes de 1930, a Corte Suprema era composta por oito ministros nomeados por Vargas, os já citados Carvalho Mourão e Plínio Casado além de Carlos Maximiliano, Ataulpho de Paiva, Costa Manso, Octavio Kelly, Laudo de Camargo e Eduardo Espínola. Persistiam ainda no Tribunal Bento de Faria, empossado por Artur Bernardes, Edmundo Lins, nomeado por Venceslau Brás e Hermenegildo de Barros, empossado por Delfim Moreira. Abaixo pode ser visto um quadro elaborado para melhor visualização: 
Quadro 1- Ministros e presidentes que os nomearam

\begin{tabular}{|l|c|c|}
\hline \multicolumn{1}{|c|}{ Ministro } & Presidente & Data em que assumiu \\
\hline Bento de Faria & Artur Bernardes & $19 / 8 / 1925$ \\
\hline Carlos Maximiliano & Vargas & $4 / 5 / 36$ \\
\hline Ataulpho de Paiva & Vargas & $20 / 3 / 1934$ \\
\hline Costa Manso & Vargas & $28 / 8 / 1933$ \\
\hline Octavio Kelly & Vargas & $14 / 02 / 1934$ \\
\hline Carvalho Mourão & Vargas & $8 / 6 / 31$ \\
\hline Laudo de Camargo & Vargas & $9 / 6 / 1932$ \\
\hline Plínio Casado & Vargas & $4 / 6 / 1931$ \\
\hline Eduardo Espínola & Vargas & $13 / 5 / 31$ \\
\hline Edmundo Lins & Venceslau Brás & $12 / 9 / 1917$ \\
\hline Hermenegildo de Barros & Delfim Moreira & $26 / 7 / 1919$ \\
\hline
\end{tabular}

Fonte: Elaborado pelo autor

Seria leviano afirmar que o simples fato de um ministro ter sido empossado por um presidente corresponderia automaticamente ao seu alinhamento com o Executivo. Para compreender o posicionamento destes julgadores quando do julgamento do habeas corpus de Olga Prestes, outros fatores também devem ser levados em conta, entre eles, a atuação pregressa dos ministros, sobre o que passa-se a expor de forma sucinta.

Bento de Faria, nascido no Rio de Janeiro e graduado em direito pela Faculdade de Direito do Rio de Janeiro, atuou a maior parte de sua carreira como advogado, até ser nomeado para o STF por Artur Bernardes. Pouco após a chegada de Vargas ao poder, em 1931, foi nomeado Procurador-Geral da República, cargo do qual pediu exoneração em 1934. Carlos Maximiliano, gaúcho graduado na Escola de Direito de Belo Horizonte, por sua vez, teve forte participação na política, atuando como deputado, ministro e, após o início do governo Vargas foi nomeado para o STF e, posteriormente, Consultor-Geral da República e Procurador-Geral da República (BRASIL, 2017).

Ataulpho de Paiva, carioca, estudou na Faculdade de Direito de São Paulo e atuou na maior parte de sua carreira como magistrado, passando pelos cargos de juiz municipal, pretor, juiz do Tribunal Civil e Criminal e desembargador. Costa Manso, paulista, da mesma forma graduou-se na Faculdade de Direito de São Paulo, exerceu atividades na magistratura, atuando como juiz de direito, ministro do Tribunal de Justiça do Estado de São Paulo e Procurador-Geral do Estado. Octavio Kelly, por sua vez, era natural de Niterói, estudou na Faculdade Livre de Ciências Jurídicas e Sociais e foi advogado por dez anos, vereador e deputado e depois passou para a magistratura, atuando como juiz federal até ser nomeado para o STF em 1934 (BRASIL, 2017). 
Carvalho Mourão, mineiro, cursou sua graduação na Faculdade de Direito de São Paulo e atuou como advogado e professor até sua nomeação para o STF. Laudo de Camargo, paulista, também cursou a mesma Faculdade, porém, por sua vez, fez carreira na magistratura, ocupando o cargo de juiz e ministro do Tribunal de Justiça do Estado de São Paulo. Interessante apontar, ainda, que foi interventor no governo de São Paulo em 1931 antes de ser nomeado ministro do STF. Plínio Casado, natural do Rio Grande do Sul, também graduou-se na Faculdade de Direito de São Paulo, exercendo o cargo de promotor por três anos. Depois disto foi deputado federal por duas vezes, advogado e interventor federal no estado do Rio de Janeiro de outubro de 1930 a maio de 1931, tomando posse como ministro do STF no mês seguinte (BRASIL, 2017).

Eduardo Espínola, baiano, estudou na Faculdade de Direito de Recife e atuou especialmente como membro do Ministério Público na Bahia, enquanto Edmundo Lins, mineiro, obteve o grau de bacharel pela Academia de Direito de São Paulo (posteriormente Faculdade de Direito de São Paulo) e ocupou cargos na magistratura mineira até passar a atuar no STF, sendo ele o Presidente da Corte quando do julgamento de Olga Benário. Por fim, Hermenegildo de Barros, mineiro, também graduou-se pela Faculdade de Direito de São Paulo e exerceu cargos na magistratura, passando de juiz de direito para desembargador em Minas Gerais, cargo que ocupou até sua nomeação para o STF (BRASIL, 2017). Para melhor visualização pode-se também organizar estes dados em um quadro:

Quadro 2- Ministro e Atuação Anterior

\begin{tabular}{|l|c|}
\hline \multicolumn{1}{|c|}{ Ministro } & Atuação Anterior \\
\hline Bento de Faria & Advocacia \\
\hline Carlos Maximiliano & Funções Políticas \\
\hline Ataulpho de Paiva & Magistratura \\
\hline Costa Manso & Magistratura \\
\hline Octavio Kelly & Magistratura \\
\hline Carvalho Mourão & Advocacia \\
\hline Laudo de Camargo & Funções Políticas \\
\hline Plínio Casado & Funções Políticas \\
\hline Eduardo Espínola & Ministério Público \\
\hline Edmundo Lins & Magistratura \\
\hline Hermenegildo de Barros & Magistratura \\
\hline
\end{tabular}

Fonte: Elaborado pelo autor 
Utilizando-se destes dados a respeito da atuação pregressa dos componentes da Corte Suprema quando do julgamento do habeas corpus de Olga Prestes, pode-se perceber que a vasta maioria dos membros da Corte havia atuado na magistratura ou exercido funções políticas (incluindo-se nesta categoria Laudo de Camargo por ter atuado como interventor durante o governo Vargas). Tendo por base pesquisas realizadas a respeito do comportamento dos julgadores durante o processo decisório (ABAL, 2016) percebe-se algumas tendências baseadas na carreira pregressa dos juízes que somadas a outros fatores podem auxiliar na compreensão das decisões judiciais.

De forma breve, julgadores de Cortes Superiores cuja atuação anterior se deu na magistratura possuem uma tendência a seguir as regras (leis, normas, decretos) independentemente de seu caráter, afastando questões morais de seus julgamentos, pendendo para um legalismo estrito (TATE, 1981; ABAL, 2016). No caso da atuação anterior se dar em funções políticas, é mais notável o interesse em se alinhar às tendências políticas, especialmente no que diz respeito ao Poder Executivo. Ex-membros do ministério público, segundo pesquisa realizada por Neal Tate nos Estados Unidos, tendem a decidir de forma mais conservadora, enquanto seus pares oriundos da advocacia são mais propensos à defesa das liberdades individuais (1981) e são menos restritos à lei para emitir suas opiniões (ABAL, 2016).

Permanecendo no que tange à vida pregressa dos julgadores, deve-se destacar que, dos onze ministros que compunham a Corte à época do julgamento, sete haviam cursado sua graduação em Ciências Jurídicas e Sociais na Faculdade de Direito de São Paulo, ou seja mais de 63\%, como pode ser visto no quadro abaixo:

Quadro 3- Ministro e sua graduação

\begin{tabular}{|l|l|}
\hline \multicolumn{1}{|c|}{ Ministro } & \multicolumn{1}{c|}{ Atuação Anterior } \\
\hline Bento de Faria & Faculdade de Direito do Rio de Janeiro \\
\hline Carlos Maximiliano & Escola de Direito de Belo Horizonte \\
\hline Ataulpho de Paiva & Faculdade de Direito de São Paulo \\
\hline Costa Manso & Faculdade de Direito de São Paulo \\
\hline Octavio Kelly & Faculdade Livre de Ciências Jurídicas e Sociais \\
\hline Carvalho Mourão & Faculdade de Direito de São Paulo \\
\hline Laudo de Camargo & Faculdade de Direito de São Paulo \\
\hline Plínio Casado & Faculdade de Direito de São Paulo \\
\hline Eduardo Espínola & Faculdade de Direito de Recife \\
\hline Edmundo Lins & Faculdade de Direito de São Paulo \\
\hline Hermenegildo de Barros & Faculdade de Direito de São Paulo \\
\hline
\end{tabular}

Fonte: Elaborado pelo autor 
Neste sentido, pode-se utilizar os estudos de Sérgio Adorno (1988) no que tange à formação que estes ministros tiveram, uma vez que, apesar da pesquisa de Adorno se referir a um período diverso (1831-1883, especialmente), os julgadores em questão graduaram-se entre 1886 e 1902, ou seja, em data muito próxima.

Nesta senda, pode-se afirmar que o fato do local predominante de formação dos julgadores ter sido a Faculdade de Direito de São Paulo também pode ter tido influência no processo decisório dos ministros, uma vez que, conforme Adorno, os estudantes desta instituição, apesar de carecerem de um ensino científico de maior qualidade, participaram ativamente de movimentos políticos, culminando na afirmação de que a Faculdade de Direito de São Paulo "moralizou o universo da política ao formar uma intelligentsia capaz de se pôr à frente dos negócios públicos e de ocupar os principais postos diretivos do Estado" (ADORNO, 1988, p. 155).

Ainda, deve-se somar a isto a tendência da Academia de São Paulo a dirigir sua formação de acordo com os interesses que a suportavam, tanto política quanto economicamente, voltandose para um pragmatismo e autoritarismo destinado a formar uma liderança teórico-ideológicopolítica (NEDER, 1995, p. 105-106).

Mais afeitos à questão política do que propriamente jurídica, oriundos majoritariamente da magistratura e de funções políticas e nomeados em sua maioria pelo próprio Vargas, já se pode traçar uma linha de afinidade entre os anseios do poder executivo e as decisões que seriam tomadas por esta Corte.

Ainda deve-se levar em conta dois fatores: o contexto histórico em que a decisão foi prolatada e as regras que foram utilizadas (ABAL, 2016). Quando do julgamento do habeas corpus de Olga Prestes, conforme exposto, o governo Vargas atuava no sentido de perseguir os seus adversários políticos, realizando, inclusive, alterações constitucionais para equiparar eventuais comoções internas a um estado de guerra. Tal previsão foi utilizada pouco antes do julgamento em tela quando em 21 de março de 1936 foi editado o Decreto 702, o qual dispunha em seu preâmbulo:

Attendendo a que novas diligencias e investigações revelaram grave recrudescimento das actividades subversivas das instituições politicas e sociaes;

Attendendo a que se tornam indispensaveis as mais energicas medidas de prevenção e repressão;

Attendendo a que é dever fundamental do Estado defender, a par das instituições, os principios da autoridade e da ordem social [...] (BRASIL, 1936).

Assim, politicamente, o Poder Executivo utilizava-se de poderes excepcionais conferidos pelo Legislativo com fins de atacar aqueles contrários ao governo Vargas, especialmente os envolvidos no ato descrito no artigo $1^{\circ}$ do Decreto que instaurava o estado de guerra por noventa dias: "a commoção intestina grave articulada em diversos pontos do paiz desde novembro de 
1935, com a finalidade de subverter as instituições politicas e sociaes" (BRASIL, 1936), ou seja, Prestes e seus companheiros. Os artigos $2^{\circ}$ e $3^{\circ}$ do Decreto também são fundamentais, uma vez que estabelecem o caráter de exceção da norma e o tratamento jurídico que seria dado aos tidos como subversivos:

Art. $2^{\circ}$ Durante o período a que se refere o artigo anterior, ficarão mantidas, em toda sua plenitude, as garantias constantes dos numeros 1, 5, 6, 7, 10, 13, 15, 17, 18, 19, 20, 28, 30, 32, 34, 35, 36 e 37, do art. 113 da Constituição da República, ficando suspensas, nos termos do art. 161, as demais garantias especificadas no citado art. 113 e bem assim as estabelecidas, explicita ou implicitamente, no art. 175 e em outros artigos da mesma Constituição.

Art. $3^{\circ} \mathrm{O}$ ministro de Estado da Justiça e Negócios Interiores superintenderá a execução das medidas decorrentes das disposições anteriores, expedindo, para esse fim, as instrucções que se tornarem necessárias. (BRASIL, 1936).

Desta forma, pode-se verificar algumas características da Corte Suprema (STF) quando do julgamento do habeas corpus de Olga Prestes: 1) oitos dos onze ministros da Corte haviam sido nomeados por Vargas. Bento de Farias, mesmo tendo sido indicado por outro presidente, foi nomeado Procurador-Geral da República por Vargas em 1931, ou seja, acabou tendo alguma vinculação com o novo governo. Gize-se, ainda, que dois dos ministros também haviam atuado como interventores durante o governo Vargas. Utilizando-se deste fator, a Corte como um todo tendia a um alinhamento com o Poder Executivo; 2) a maioria dos ministros (oito) havia exercido, antes de ingressar na Corte, cargos ligados à magistratura ou a funções políticas, o que pode indicar, de um lado, uma obediência mais estrita à lei no momento de efetuar seus julgamentos no caso dos magistrados e, de outro, uma maior tendência a seguir as intenções do Poder Executivo, no caso dos que exerceram funções políticas; 3) as regras que deveriam ser utilizadas pelos ministros durante o julgamento eram excepcionais, trazidas através de um Decreto que estabelecia o estado de guerra e suspendia diversas garantias constitucionais, reduzindo a possibilidade dos julgadores decidirem de forma contrária aos anseios do Poder Executivo; e 4) o contexto histórico em que o julgamento ocorreu demonstra uma pouca margem para os ministros decidirem livremente, uma vez que Vargas já havia se mostrado disposto a alterar a competência e até mesmo a composição do Tribunal. Assim, como forma de proteger o seu próprio cargo e a Corte como instituição, seria previsível o alinhamento do Tribunal à vontade do governo Vargas.

Estas observações vão ao encontro do que dispôs Emília Viotti da Costa sobre o STF durante o governo Vargas, apesar da autora referir-se ao Estado Novo: 
Diante desse rol de ministros que ocuparam lugar no Supremo Tribunal Federal graças à indicação do presidente Vargas, é possível concluir: ou era ele mais liberal do que se tem dito e tolerava uma relativa diversidade de opiniões, ou os ministros partilhavam até certo ponto de suas ideias, ou pelo menos estavam dispostos a atuar dentro das limitações que lhes foram impostas durante o Estado Novo. Por meio de várias medidas, Vargas reduzira a competência do Supremo, transformando-o, de certo modo, em um instrumento do regime (COSTA, 2006, p. 74).

Tendo em vista todos esses fatores e, especialmente, as limitações enfrentadas pelos julgadores e a tendência a um alinhamento com os anseios do governo Vargas quando do julgamento do habeas corpus de Olga Prestes, pode-se passar agora à análise do julgamento em si.

\section{O julgamento do habeas corpus em nome de Olga Prestes}

Em 03 de junho de 1936 foi protocolado na Corte Suprema dos Estados Unidos do Brasil o habeas corpus de número 26155 pelo advogado Heitor Lima em favor de Maria Prestes (nome que era utilizado por Olga no país). Lima fora indicado por Prestes para defender Olga juntamente com Justo de Moraes e Evaristo de Morais, porém os dois últimos haviam recusado a causa (REIS, 2014, p. 201), sendo desconhecido o motivo.

O habeas corpus impetrado era bastante peculiar. Como não haviam sido encontrados nos documentos recolhidos pelas forças policiais indícios claros da participação de Olga e suas funções entre os comunistas (NUNES, 2015, p. 126), ela não seria processada junto com Prestes e os demais, restando a Vargas uma prerrogativa do Poder Executivo, a expulsão, instituto jurídico que pode ser descrito da seguinte forma:

Trata-se de uma ilação, porquanto do mesmo modo que o Estado tem a faculdade de impedir a entrada de estrangeiro nocivo à ordem pública interna, também lhe assiste o direito de expulsá-lo quando estiver perturbando a tranquilidade do grupo. É, portanto, meio de defesa do Estado (AMORIM; OLIVEIRA JÚNIOR, 2011, p. 73).

A expulsão de estrangeiro estava prevista na Constituição de 1934 em seu artigo 113, n 15, que dispunha "A União poderá expulsar do território nacional os estrangeiros perigosos à ordem pública ou nocivos aos interesses do País". Assim, mesmo sem um procedimento judicial, Olga poderia ser expulsa do Brasil para seu país de nascimento, a Alemanha.

A peculiaridade referida advém da utilização do instrumento do habeas corpus diante de sua finalidade. Vejamos: segundo Slaibi Filho o habeas corpus é "remédio jurídico processual, de 
fundamento constitucional, legitimando qualquer pessoa a ingressar junto ao Poder Judiciário para a proteção da liberdade de locomoção própria ou de terceiro" (SLAIBI FILHO, 2009, p. 369). Assim, o habeas corpus seria um meio para proteger a liberdade de locomoção de uma pessoa. O texto elaborado pelo advogado de Olga, porém, não se limitava a isto.

O habeas corpus iniciava expondo a situação de Olga, presa na Casa de Detenção em total incomunicabilidade em virtude de sua participação, direta ou indireta, nos acontecimentos de novembro de 1935. Passou, então, o advogado a alegar que a todos se aplicaria a lei penal, independentemente de suas peculiaridades. Havendo qualquer ato de delinquência, deveria ser aplicada a lei através de um julgamento. Caso um estrangeiro fosse perigoso, porém não criminoso, poderia, então, aplicar-se a expulsão. Neste instante a peça judicial realizada assume um caráter curioso que podemos transcrever com a grafia inalterada:

Em que situação se encontra a paciente, e em face della o Estado? Maria Prestes foi presa como delinquente, indiciada em factos punidos com grande rigor. A policia [...] não faz mysterio de que contra a paciente colligiu elementos de summa importancia, e tem como certa a sua condemnação. Se a policia não exagera, também esta é a conviç̧ão do impetrante: Maria Prestes será condemnada. Mas condemnada por que autoridade? Pela unica investida das funcções de julgar: a autoridade judiciaria. Que pretende, porém, o Ministerio da Justiça? Dispõe-se a remetter os autos do inquerito ao juizo competente? Não. Pretende dar à paciente, como premio aos delictos que lhe attribue, a liberdade sob a forma de expulsão (BRASIL, 1936).

Como se pode ver, Heitor Lima não alegava a inocência de Olga, pelo contrário, afirmava que as provas existentes seriam capazes de condená-la em juízo ${ }^{2}$ caso ela fosse a julgamento. A expulsão não seria uma penalidade para ela, mas um prêmio, a concessão da liberdade. Requeria o advogado, então, que Olga fosse julgada e, caso condenada, cumprisse a pena devida. Após o cumprimento da pena poderia ela, então, ser expulsa para que não praticasse outros crimes. Tratava-se, portanto, de um habeas corpus não para pedir a liberdade da paciente ${ }^{3}$, mas sim para que ela fosse sujeita a um julgamento por um tribunal brasileiro sem ser expulsa.

Após isto, passou Lima a outra linha de argumentação, a de que não seria apenas uma pessoa a ser expulsa, mas sim duas, já que "Maria Prestes traz no seio, com quatro mezes de gestação, o fruto do seu amor apaixonado, tormentoso, inexhaurivel e cego por Luiz Carlos Prestes". Tratar-se-ia, assim, de um feto gerado no país e que, mesmo ainda não tendo nascido, seria alvo de proteção da lei, dando como exemplo os direitos do nascituro constantes no

\footnotetext{
${ }^{2}$ Talvez não fosse do conhecimento do advogado, mas segundo ofício enviado ao Capitão Chefe de Polícia, não haviam sido recolhidas provas suficientes contra Olga para que figurasse como acusada no inquérito (NUNES, 2015, p. 127).

${ }^{3}$ Termo utilizado para designar o alvo da proteção requerida pelo habeas corpus.
} 
Código Civil da época e o crime de aborto o qual, sendo uma espécie de homicídio, realizava a proteção da criança mesmo antes do parto.

Desta maneira, sendo a gestante e o nascituro duas pessoas diferentes, deveriam ser resguardados os direitos de ambos. Fundamentou o advogado, então, que deveria ser observado um princípio básico de direito penal instituído na Constituição, o de que nenhuma pena passará da pessoa do delinquente. Assim, tratando-se a expulsão como pena, esta não poderia alcançar também o feto sob pena de ferir também a própria proteção da maternidade prevista constitucionalmente.

A sequência da peça é composta por uma mescla de pequenos elogios e críticas nada veladas a Getúlio Vargas que, segundo Lima, "tem mostrado, como chefe de governo, surpreendentes defeitos" e afirmando que "o que lhe falta em cultura sobra-lhe em inteligência, e a intuição empresta-lhe todas as capacidades". Roga, então, a Vargas e ao diretor da Casa de Detenção, Aloysio Neiva, que tivessem compaixão com aquela mãe que desejava permanecer no Brasil, mesmo presa. Neste país, a maternidade lhe abriria os olhos e ela poderia, inclusive, ajudar a recuperar Prestes.

Finalizando sua argumentação dispôs o advogado:

Se o habeas-corpus for concedido, que succederá? Presa e incommunicavel continuará a paciente. Prosseguirá o inquerito no qual a policia vê fortes elementos para condemnação. O poder judiciario, tomando conhecimento das provas que a policia affirma irrefragaveis contra a paciente condemnal-a-á. Ficará assim Maria Prestes reduzida á condição de nada fazer de nocivo á ordem publica. Mas, embora presa e condemnada, muito poderá fazer de util, como esposa e mãe (BRASIL, 1936).

Requereu, por fim, que fosse dispensada a paciente do pagamento de custas, uma vez que não possuía condição de pagá-las e que fosse concedido o habeas corpus para que Olga não fosse expulsa do país, entre outros requerimentos. O primeiro despacho, feito à mão pelo ministro Edmundo Lins, indeferiu o pedido de dispensa do pagamento de custas. $O$ mais simples dos requerimentos de Heitor Lima havia sido negado. O próprio advogado, então, pagou as despesas do processo, mas não sem expor sua indignação:

Se a justiça masculina, mesmo quando exercida por uma consciência do mais fino quilate, como o insigne presidente da Corte Suprema, tolhe a defesa a uma encarcerada sem recursos, não há de a historia da civilização brasileira recolher em seus annaes judiciários o registro desta nodoa; a condemnação de uma mulher, sem que a seu favor se elevasse a voz de um homem no Palácio da Lei. O impetrante satisfará as despesas do processo (BRASIL, 1936). 
Pagas as despesas, protocolado o habeas corpus e juntados documentos pelo Ministério da Justiça informando que realmente tramitava contra Olga um processo de expulsão, cabia agora à Corte Suprema brasileira a decisão a respeito de Olga Prestes e da criança que gestava. Podemos passar agora ao estudo da decisão da Corte a respeito do caso.

O acórdão da Corte Suprema em relação ao habeas corpus em nome de Maria Prestes foi prolatado em 17 de junho de 1936 sob a relatoria do ministro Bento de Faria. Nos documentos obtidos junto ao Supremo Tribunal Federal não consta o relatório e voto do relator, Bento Faria, porém podem ser abstraídos dos votos elementos suficientes para conhecer o seu conteúdo. É possível verificar o posicionamento do ministro a seguir, na análise dos demais votos.

O primeiro ministro a expor seu voto foi Carlos Maximiliano. O ministro indicou que o argumento mais forte seria o de que Olga era acusada de um crime inafiançável e, portanto, deveria ser processada anteriormente para que depois pudesse ocorrer a expulsão. Segundo Maximiliano, porém, não haviam provas de que Olga estivesse sendo processada, existindo, inclusive, uma informação da autoridade policial declarando que não estava em curso processo criminal que pudesse levar à prisão da paciente.

Outro argumento do habeas corpus, o de que caso Olga fosse presa e permanecesse no país ela poderia recuperar Prestes, também foi repelido pelo ministro pelo fato de "os homens serem alojados em compartimentos isolados dos destinados às damas", o que seria um impeditivo do contato entre os dois. Ingressando na questão da proteção ao filho não nascido de Olga, Maximiliano entendeu que não poderia existir um habeas corpus para "um feto, para lhe reconhecer o direito de sair das entranhas maternas", até mesmo porque não se saberia se a concepção havia ocorrido no Brasil.

Na sequência, o ministro continuou a versar sobre a alegada expulsão do feto, expondo as proibições no tocante à expulsão previstas na Constituição vigente à época. Segundo a Carta de 1934, não poderiam ser expulsos cidadãos brasileiros, sendo tidos como brasileiros os nascidos no Brasil, os filhos de brasileiro nascidos no exterior com os pais em serviço público ou que optarem posteriormente pela nacionalidade brasileira e os estrangeiros naturalizados. Como o filho de Olga ainda não havia nascido, não poderia se encaixar em nenhuma destas hipóteses. Desta forma, Maximiliano aceitou o pedido, porém o indeferiu, dizendo divergir do relator, que não havia conhecido ${ }^{4}$ do pedido.

$O$ voto do ministro Ataulpho de Paiva foi bastante sucinto, realizado em apenas duas linhas, dizendo que não conhecia do pedido, porém, caso fosse vencido neste aspecto, indeferia-o no mérito. O ministro Costa Manso, por sua vez, produziu um voto mais extenso, detendo-se, em primeiro lugar, na questão da possibilidade de se impetrar habeas corpus durante o estado de guerra, o qual, como já visto, estava em vigor, decretado por Vargas.

\footnotetext{
${ }^{4} \mathrm{~A}$ palavra conhecimento, neste caso, deve ser entendida em seu conceito jurídico, ou seja, o recebimento e apreciação da peça. No decorrer do artigo, o não conhecimento do habeas corpus significa que ele não foi apreciado pelo ministro por este entender que não estão presentes os requisitos necessários.
} 
De acordo com Costa Manso haviam três correntes no Tribunal, a primeira, seguida por Bento de Faria posicionava-se no sentido de que o instituto estaria totalmente suspenso neste caso. A segunda seria oriunda do pensamento do ministro Plinio Casado que, em outra oportunidade, sustentou, sendo seguido pela maioria da Corte, que o habeas corpus não seria admissível quando o constrangimento contra o paciente vier de motivos de ordem pública. A última corrente seria a mais liberal, diferenciando-se da segunda ao defender que é cabível o habeas corpus mesmo em casos envolvendo a ordem pública quando houvesse decisão judicial. Para o ministro, porém, as três correntes convergiam em um ponto: "não cabe habeas-corpus quando se trate de medida de segurança, determinada pelo Poder Executivo e seus agentes, para manutenção da ordem pública”. Assim, sequer existindo processo judicial contra Olga Prestes, não poderia se aplicar habeas corpus ao caso.

Quanto ao estado de gravidez de Olga, entendeu o ministro que "o argumento é de ordem puramente sentimental, pois ninguém pode interpretar a vontade de um feto". Mesmo que a expulsão de uma pessoa acabasse gerando o exílio de toda uma família essa deveria ser levado a cabo, já que "a defesa da ordem pública num país tem dessas exigências. O bem público está acima de tudo". A parte final do voto do ministro, em que consta sua decisão, chama a atenção, uma vez que ele utiliza dos próprios argumentos do advogado de Olga para distorcer a sua finalidade:

Ora, o impetrante expressamente declara que não pede seja a paciente, que se acha presa, restituída à liberdade. Quer que continue presa, seja julgada, condenada e cumpra a pena que lhe for imposta, para, só então, ser expulsa do país! O Governo, mais benigno, livra-a imediatamente da prisão, concedendolhe a liberdade, embora além das fronteiras! Não posso tomar conhecimento de um pedido, de que resulta manifesto prejuízo para a liberdade da paciente! (BRASIL, 1936).

O ministro Octavio Kelly também foi bastante sucinto, não conhecendo do habeas corpus pelo motivo de que este não poderia ser utilizado quando do estado de guerra. Carvalho Mourão, por sua vez, prolatou o mais extenso voto constante no acórdão. Já no início de sua exposição afirmou que não iria repelir o pedido imediatamente, como fizera Bento Faria, uma vez que via no pedido uma questão que, apesar de improcedente, merecia um exame aprofundado: a situação do nascituro e sua proteção.

O feto não teria personalidade diante da codificação brasileira, uma vez que esta inicia com o nascimento com vida, porém, em algumas situações, a lei previa a salvaguarda do nascituro desde o momento da concepção. Questionava, então, o ministro, o direito de nacionalidade da criança que estava sendo gestada por Olga. Para ele, a proteção do nascituro, presente em alguns casos, tratava-se de uma ficção jurídica, a qual só poderia ser aplicada quando da existência de previsão legal. Como a nacionalidade era prevista pela Constituição, apenas a 
Carta Magna poderia dispor acerca deste assunto. Ao prever que apenas os nascidos no Brasil teriam nacionalidade brasileira, o que confere a nacionalidade não seria a concepção, mas sim o nascimento. Mesmo sabedor de que Olga seria expulsa para a Alemanha nazista, afirmou Carvalho Mourão que "a circunstância de a gestante mudar de domicílio não põe em perigo a vista do nascituro".

Superada esta alegação do advogado, passou o ministro a analisar a questão da existência de um processo criminal que impediria a expulsão de Olga. Entendeu Carvalho Mourão que se tratava de uma prerrogativa do Estado. Para ele, o governo poderia expulsar qualquer um mesmo havendo processo criminal. Além disso, segundo as provas constantes nos autos, não havia qualquer processo contra Olga. Assim, Carvalho Mourão conheceu do pedido de habeas corpus, mas negou-o.

Os votos seguintes são extremamente curtos. Laudo de Camargo disse que a questão de segurança nacional não poderia ser tratada pelo Poder Judiciário, e não conheceu do pedido. Da mesma forma agiu Plinio Casado ao expor que a concessão do habeas corpus poderia prejudicar a segurança nacional. Eduardo Espínola conheceu do pedido remetendo aos argumentos de Carvalho Mourão, porém o indeferiu por afetar a segurança nacional. A decisão estava pronta para publicação: "Não conheceram do pedido, contra os votos dos senhores Ministros Carlos Maximiliano, Carvalho Mourão e Eduardo Espínola, que conheciam e indeferiam".

Pouco mais de dois meses depois da decisão da Corte Suprema foi decretada a expulsão de Olga Prestes em documento assim redigido:

O PRESIDENTE DOS ESTADOS UNIDOS DO BRASIL, Considerando que a allemã Maria Bergner Villar, que também usa os nomes de Frieda Wolff Bertrand, Olga Bergner, Olga Benario, Olga Meirelles, Maria Prestes e Erna Kruger, se tem constituído elemento nocivo aos interesses do paiz e perigoso á ordem publica; conforme foi apurado pela Policia do Districto Federal; Resolve, em conformidade com o dispôsto no art. $^{\circ} 113$, n. ${ }^{\circ}$ 15, da Constituição Federal, expulsar a referida estrangeira do território nacional. Rio de Janeiro, em 27 de agosto de 1936, $115 .{ }^{\circ}$ da Independência, $48{ }^{\circ}$ da República. (a) Getulio Vargas. (a) Vicente Ráo. Secretaria de Estado da Justiça e Negócios Interiores. Registrado às fls. 65 do livro respectivo. Diretoria da Justiça, 1a Secção, em 27 de agosto de 1936 (BRASIL, 1936).

Em outubro de 1936 Olga era enviada à Alemanha no navio La Coruña. No dia 27 de novembro nascia no Campo de Concentração de Barnimstrasse em Berlim uma menina, Anita Leocádia Prestes, que em janeiro de 1938, graças a uma grande campanha internacional, foi entregue à avó, Leocádia, mãe de Prestes, salvando a criança de que fosse enviada a um orfanato nazista. Em 1942, com apenas 34 anos de idade, Olga foi morta em uma câmara de gás no campo de Bernburg. 


\section{Considerações Finais}

A expulsão de Olga Prestes, grávida, somada à sua consequente morte em um campo de concentração alemão é descrita em determinados momentos como uma ação natural em virtude do caráter do governo varguista e, em outros, como uma nódoa indelével na história do Supremo Tribunal Federal. O presente artigo pretendeu não encarar com normalidade a decisão, mas sim analisar os fatores que, somados, levaram à expulsão de Olga.

Iniciando as considerações finais, deve-se destacar estes fatores citados que tiveram influência no processo decisório dos julgadores no que tange ao habeas corpus em tela. Primeiramente, pôde ser visto que o caráter do movimento de 1935 encabeçado por Luís Carlos Prestes era de extrema oposição a Vargas. Este, por sua vez, estava ciente da periculosidade ao seu governo da figura de Prestes e dos comunistas em geral. Desta forma, tomou todas as atitudes possíveis para acabar com as ações da chamada "intentona" comunista e, posteriormente, para punir e neutralizar politicamente os envolvidos. Dentre estas atitudes muitas passavam pelo plano jurídico-legal, motivo pelo qual Vargas acabou promovendo alterações legislativas para facilitar a repressão aos opositores do seu governo.

Desde a chegada de Vargas ao poder este tentou subtrair atribuições do Supremo Tribunal Federal e intervir neste Tribunal tendo por objetivo possuir uma forte influência na Corte e obter decisões favoráveis aos seus interesses. Quando do julgamento do habeas corpus em favor de Olga Prestes, oito dos onze ministros da Corte Suprema haviam sido nomeados por Vargas, e um dos restantes, Bento de Farias, teve também uma relação com o poder executivo ao ser nomeado Procurador-Geral.

Uma proporção significativa de ministros (cinco) havia exercido, antes de ingressarem na Corte Suprema, atividades ligadas à magistratura. Julgadores de Cortes Supremas com antecedentes profissionais na magistratura possuem uma tendência a decidir de forma mais restrita à lei, seguindo as regras existentes sem interferência de questões morais. Como pôde ser visto, as regras em vigor na época do julgamento eram voltadas para a repressão aos opositores de Vargas, que havia equiparado os movimentos de 1935 a um estado de guerra, suspendendo diversas garantias constitucionais e, entre elas, o próprio habeas corpus. Assim, limitadas as regras passíveis de utilização, a maioria dos membros da Corte (oito) votou pela impossibilidade de conhecer do habeas corpus.

Três ministros, ainda, haviam exercido funções políticas antes de ingressarem na Corte Suprema, ou seja, já possuíam uma relação anterior com o poder executivo, do que pode se inferir uma maior propensão a seguirem os anseios do presidente no que tange às suas decisões. Ainda, sete ministros haviam realizado sua graduação no mesmo local: a Faculdade de Direito de São Paulo, conhecida mais pela formação de bacharéis voltados para a política do que pela sua qualidade no ensino jurídico propriamente dito. 
Além destes fatores pessoais, ligados à atuação anterior dos julgadores, e da própria restrição trazida pelas regras que deveriam ser utilizadas durante o julgamento, deve-se ressaltar o contexto histórico em que a decisão foi prolatada. A questão dos membros do poder judiciário em análise seguirem um posicionamento alinhado com o poder executivo tratava-se também de uma tentativa de proteger a sua posição e a própria Corte Suprema como instituição. As mudanças realizadas por Vargas em relação à composição da Corte e sua competência era um claro aviso de que ele estava disposto a interferir no Tribunal para garantir que seus anseios fossem satisfeitos. Caso houvesse uma decisão contrária a Vargas, não é difícil vislumbrar que este conseguiria realizar uma nova alteração, já que pouco tempo antes já obtivera vitórias junto ao poder legislativo.

Tendo estes fatores em vista, pode-se finalizar afirmando que a decisão da Corte Suprema no julgamento do habeas corpus em favor de Olga Prestes estava alinhada com os anseios do poder executivo em reprimir e punir os opositores ao governo de Vargas. Este alinhamento, por sua vez, não era oriundo apenas da nomeação dos ministros por parte de Vargas, mas também do regramento jurídico existente e modificado por Vargas e da necessidade de proteção da posição dos ministros e da própria Corte como instituição.

\section{Referências}

ABAL, Felipe Cittolin. O oscilar da balança: o processo decisório na extradição de fugitivos nazistas em uma análise histórico-jurídica. 2016. Tese (Doutorado em História) - Universidade de Passo Fundo, Passo Fundo, 2016.

ADORNO, Sérgio. Os aprendizes do poder. Rio de Janeiro: Paz e Terra, 1988.

AMORIM, Edgar Carlos de; OLIVEIRA JÚNIOR, Vicente de Paulo Augusto. Direito internacional privado. Rio de Janeiro: Forense, 2011.

BRASIL. Decreto $n^{\circ} 702$, de 21 de março de 1936. Declara pelo prazo de noventa dias, equiparada ao estado de guerra, a comoção intestina grave, em todo o território nacional. Disponível em: <http://www2.camara.leg.br/legin/fed/decret/1930-1939/decreto-702-21-marco-1936-472177publicacaooriginal-1-pe.html>. Acesso em: 9 nov. 2017.

BRASIL. Supremo Tribunal Federal. Habeas Corpus 26.155. Maria Prestes. Jun. 1936.

BRASIL. Supremo Tribunal Federal. Ministros. Disponível em: <http://www.stf.jus.br/portal/ ministro/ministro.asp?periodo=stf\&tipo=alfabetico $>$. Acesso em: 31 jan. 2017.

CARVALHO, José Murilo. Cidadania no Brasil: o longo caminho. 23. ed. Rio de Janeiro: Civilização Brasileira, 2017. 
CARVALHO, José Murilo. Cidadania no Brasil: o longo caminho. 3. ed. Rio de Janeiro: Civilização Brasileira, 2002.

COSTA, Emília Viotti. STF: O Supremo Tribunal Federal e a construção da cidadania. 2. ed. São Paulo: UNESP, 2006.

FAUSTO, Boris. História do Brasil. 2. ed. São Paulo: USP, 1995.

KOERNER, Andrei. Judiciário e cidadania na Constituição da República Brasileira (1841-1920). Curitiba: Juruá, 2010.

MORAIS, Fernando. Olga. São Paulo: Companhia das Letras, 2008.

NEDER, Gizlene. Discurso jurídico e ordem burguesa no Brasil. Porto Alegre: Sergio Antonio Fabries Editor, 1995.

NUNES, Diego. L'espulsione di Olga Benario. Legalità ed eccezione davanti alla Corte Suprema brasiliana nell'era Vergas. Quaderni del Dipartimento Jonico. 2015. Disponível em: <www. annalidipartimentojonico.org>. Acesso em: 28 jan. 2017.

PRESTES, Anita Leocadia. Olga Benario Prestes: uma comunista nos arquivos da Gestapo. São Paulo: Boitempo, 2017.

PRESTES, Luís Carlos. Manifesto da Aliança Nacional Libertadora. 1935. Disponível em: <https:// www.marxists.org/portugues/prestes/1935/07/05.htm>. Acesso em: 27 jan. 2017.

REIS, Daniel Aarão. Luís Carlos Prestes: um revolucionário entre dois mundos. São Paulo: Companhia das Letras, 2014.

SKIDMORE, Thomas E. Brasil: de Getúlio Vargas a Castelo Branco, 1930-1964. 14. ed. Rio de Janeiro: Paz e Terra, 2007.

SLAIBI FILHO, Nagib. Direito constitucional. Rio de Janeiro: Forense, 2009.

TATE, Neal. Personal attribute models of the voting behavior of U.S. supreme court justices: liberalism in civil liberties and economics decisions, 1946-1978. The American Political Science Review, Baltimore, v. 75, n. 2, p. 362, June 1981.

VIANNA, Marly de Almeida G. O PCB, a ANL e as insurreições de novembro de 1935. In: FERREIRA, Jorge; DELGADO, Lucilia de Almeida Neves (Org.). O tempo do nacional-estatismo: do início da década de 1930 ao apogeu do Estado Novo. 2. ed. Rio de Janeiro: Civilização Brasileira, 2007. 